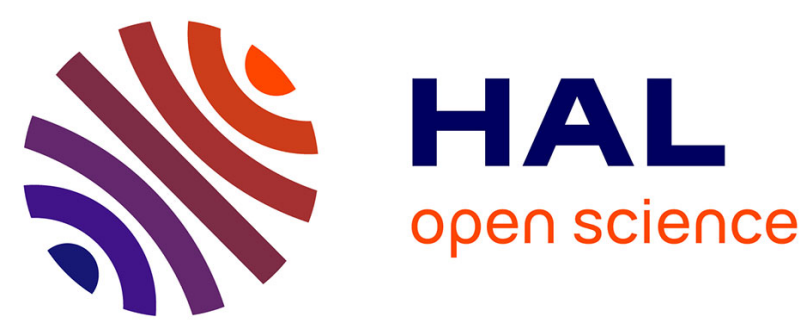

\title{
Almsgiving, Donatio Pro Anima and Eucharistic Offering in the Early Middle Ages of Western Europe (4th - 9th century)
}

Eliana Magnani

\section{- To cite this version:}

Eliana Magnani. Almsgiving, Donatio Pro Anima and Eucharistic Offering in the Early Middle Ages of Western Europe (4th - 9th century). Miriam Frenkel; Yaacov Lev. Charity and Giving in Monotheistic Religions, 22, Walter de Gruyter, pp.111-121, 2009, Studien zur Geschichte und Kultur des islamischen Orients. Beihefte zur Zeitschrift “ Der Islam ”, 9783110216837. 10.1515/9783110216837.1.111. halshs-00440884

\section{HAL Id: halshs-00440884 \\ https://shs.hal.science/halshs-00440884}

Submitted on 16 Aug 2021

HAL is a multi-disciplinary open access archive for the deposit and dissemination of scientific research documents, whether they are published or not. The documents may come from teaching and research institutions in France or abroad, or from public or private research centers.
L'archive ouverte pluridisciplinaire HAL, est destinée au dépôt et à la diffusion de documents scientifiques de niveau recherche, publiés ou non, émanant des établissements d'enseignement et de recherche français ou étrangers, des laboratoires publics ou privés. 


\title{
Almsgiving, Donatio Pro Anima and Eucharistic Offering in the Early Middle Ages of Western Europe (4th -9 th century) ${ }^{*}$
}

(published in Charity and Giving in Monotheistic Religions, edited by Miriam Frenkel, Yaacov Lev, Berlin, Walter de Gruyter, 2009, p. 111-121 (Studien zur Geschichte und Kultur des islamischen Orients. Beihefte zur Zeitschrift « Der Islam », Neue Folge Band 22) (ISBN 978-3-11-020946-4)

\author{
Eliana MAGNANI \\ CNRS - Centre National de la Recherche Scientifique \\ ARTeHIS - UMR 5594 - Auxerre/Dijon
}

During the early Middle Ages in Western Europe, charity practice, the pro anima donations and alms given to churches and monasteries, had at its heart a complex system of historically defined representations in which the Eucharistic offering stood for a model of the exchanges between men and God. This system of representation evolved in three discrete periods of time, as we see through an exploration of writings on the doctrine of almsgiving and of epigraphic inscriptions and diplomatic acts from the fourth through the ninth centuries. From the fourth to the sixth century, the doctrine of almsgiving developed as a result of the creation of the social category of the poor, an evolution that affected the behaviour of the aristocracy. Following this development, in the seventh and eighth centuries, as the amount of alms and gifts made to churches and monasteries increased, the clergy progressively established itself as the mediator in the exchanges between men and God. Finally, the Carolingian shift of the ninth century heralded the expansion of the seigniorial age, when the relation between the earth and heaven began to be seen as a mystery similar to that of the Eucharist. ${ }^{1}$

In late antiquity, the doctrine of almsgiving spreads through bishops' teaching, very often against old evergetic practices. As Peter Brown, Paul Veyne, and Evelyne Patlagean have documented ${ }^{2}$, between the fourth and the sixth centuries, emerges the social category of the poor -which did not exist in antiquity- created by the bishops risponsables of important transformations during the centuries of conversion to Christianity. The generic category of the poor included sub-categories of various stages of poverty: the destitute, the needy, and a wide range of "middle classes," including rich people who had lost their rank (such as widows or orphans), as well as those with

\footnotetext{
** Translated by Anne-Sophie Maret.

${ }^{1}$ Magnani, Eliana: "Du don aux églises au don pour le salut de l'âme en Occident (IV $-\mathrm{XI}^{\mathrm{e}}$ siècle): le paradigme eucharistique", Pratiques de l'eucharistie dans les Églises d'Orient et d'Occident (Antiquité et Moyen Âge), dir. Nicole Bériou, Béatrice Caseau, Dominique Rigaux (Études augustiniennes, forthcoming); Iogna-Prat, Dominique: Ordonner et exclure. Cluny et la société chrétienne face à l'hérésie, au judaïsme et à l'islam (1000-1150), Paris, Aubier, 1998. See also, about gift and charity, GuerreauJalabert, Anita: "Caritas y don en la sociedad medieval occidental", Hispania. Revista Española de Historia, 60/1/ 204 (2000), p. 27-62.

${ }^{2}$ Brown, Peter: Poverty and Leardeship in the Later Roman Empire, Hanovre-Londres, Brandeis University press, University Press of New England, 2002 (The Menahem Stern Jerusalem Lectures); Veyne, Paul: Le pain et le cirque, sociologie historique d'un pluralisme politique, Paris, Seuil, 1976; Patlagean, Evelyne: Pauvrété économique et pauvrété sociale à Byzance, $4^{e}-7^{e}$ siècles, EHESS-Mouton, Paris-La Haye, 1977 (PhD, univ. Paris IV, 1973) and "The Poor", The Byzantines, ed. G. Cavallo, Chicago, 1997, p. 15-42.
} 
unstable situations who were likely to fall into poverty. The bishop thus becomes the protector of the plebians, he who intercedes on their behalf with the imperial authorities. By reinvigorating the Old Testament model of communal solidarity of Judaism, the Christian believers were invited to make donations to support those poor dependent upon the Church and supervised by the clergy. This model of Christian donor incorporates several aspects of the civic evergetic model popularized by the converted emperor Constantine (274-337) and his successors. It transformed the traditional Christian charity in a kind of public service. Indeed, the service of caring for the poor helped to define the place of the Church in the Roman society and to control the clergy action. Additionally, the identification of Christ with the poor formed the core justification for the Church's keeping of goods in the Middle Ages.

From a theological perspective, the doctrine of almsgiving connected the salvation of man with his donations to churches, with his exchanges with God. In his third century work De opera et eleemosynis, Cyprian of Carthage (d. 258) first explicitly stated the idea (implicit in Scripture and in Greek writings) that almsgiving redeems sin. While his formulation of almsgiving as redemptive stands distinctly separate from the remission of sins made after baptism, he does link it to the general doctrine of salvation ${ }^{3}$. Cyprian's formulation of the doctrine of charity encompasses many of the biblical themes used in the following centuries and in the Middle Ages. Cyprian, along with the other bishops that follow him, does not exhort believers to give alms directly to the poor and needy, but rather to donate to the churches for bishops to ensure their distribution ${ }^{4}$. He thus asserts the roles of the Church and clergy as intermediaries to maintain the initiatives that guarantee salvation. In essence, the clergy represents the figure of the sacrificer. Moreover, by playing on the image of Christ standing behind the poor who receive alms, and by using the example of Job who offers sacrifices for his children, Cyprian compares almsgiving to sacrifice, opening it to an association with the Eucharist ${ }^{5}$.

From a very early point in Werstern history, bishops began to hold the monopoly on the organization of assistance to the needy, both by ensuring their protection and by distributing alms. As early as the fourth century, this task is proposed as a justification of the wealth of churches. According to Augustine (354-430), the collected goods did not belong to bishops but to the poor, with the bishops acting as their stewards ${ }^{6}$. In the sixth and seventh centuries, the notion that the goods of the Church belong to the poor appears very clearly in the Merovingian councils. For instance, these councils present those who

\footnotetext{
${ }^{3}$ Cyprian of Carthage: De opere et eleemosynis, (La bienfaisance et les aumônes), ed. \& trans. M. Poirier, Paris, Cerf, 1999 (Sources Chrétiennes, 440) p. 168. See Jobert, Philippe: La notion de donation, Convergences 630-750, Publ. de l'Université de Dijon, Paris,1977, p. 161-164; Garrison, Roman: Redemptive Almsgiving in Early Christianity, Sheffield, 1993 (Journal for Study of the New Testament, Supplement Series 77).

${ }^{4}$ Cyprian of Carthage: De opere et eleemosynis, introd. p. 52, 55.

${ }^{5}$ Cyprian of Carthage: De opere et eleemosynis, ch. 18 and 15.

${ }^{6}$ Augustine: Epistulae, Al. Goldbacher ed., Vindobonae, 1911 (Corpus scriptorum ecclesiasticorum latinorum 57), 185, 9, 35, p. 32: ...si autem privatim quae nobis sufficiant, possidemus, non sunt illa nostra, sed pauperum quorum procurationem quodammodo gerimus, non proprietatem nobis usurpatione damnabili vindicamus.
} 
are accused of seizing church propreties or of disrespecting their own donations as "murderer of [the] poor" [necator pauperum] $]^{7}$

The idea that the Church manages the goods of the poor gives birth to the concept that it is the depository on earth of the goods that good people will find in heaven. Isidore of Seville (died c. 636) explains that the church will keep as a security the goods which good people will find and enjoy in the future, because what matters is the use one makes of earthly goods that God indifferently distributed to good and bad people ${ }^{8}$. The clergy not only starts considering itself as a necessary intermediary for the donations made to God, but also as a guarantor for the passage of goods from here below to the beyond.

Such views, whose usefulness in social relations is obvious, are built on the Eucharistic sacrifice model, in which offerings brought by the believers are put on the altar and consecrated by the celebrant in order to be approved by God and taken to the altar "on high" by the angels' hands. Ambrose (d. 397), in his De Sacramentis (IV, 27), is the first to evoke this extract from the canon of the mass: "and we ask and pray that thou wouldst receive this oblation on thy altar on high by the hands of thy angels, as thou didst vouchsafe to receive the presents of thy righteous servant Abel, and the sacrifice of our patriarch Abraham, and that which the high priest, Melchizedek offered to thee"9.

With regard to practice, epigraphic inscriptions enable us to measure how much the doctrine of almsgiving affects the behaviour of the aristocracy, associated with a notable widening of what is considered as a donation to God. From the fourth century onwards, in the funerary inscriptions, next to the traditional qualities in connection with the noble origin of the deceased and the praise of his public career, pater pauperum, amator pauperum, pauperibus pius or pia as well as other similar expressions, present the donations for the needy as being amongst the virtues and initiatives characteristic of the

\footnotetext{
${ }^{7}$ Les Canons des conciles mérovingiens (VIe-VII e siècles), trans. J. Gaudemet, B. Basdevant, Paris, Cerf, 1989, 2 vol. (Sources Chrétiennes 353, 354): Orléans V, 549 (c. 13, 15, 16); Arles, 554 (c. 6); Tours II, 567 (c. 25, 26); Mâcon I, 581-583 (c. 4); Clichy, 626-627 (c. 12); Chalon, 647-653 (c. 6). See Pontal, Odette: Histoire des conciles mérovingiens, Paris, 1989; EWIG, Eugen: "Beobachtungen zu den Bischofslisten der Merowingischen Konzilien und Bischofsprivilegien”, H. Atsma ed., Spätantikes und Fränkisches Gallien. Gesammelte Schriften (1952-1973), t. II, Munich, 1979, p. 427-455; Champagne, Jacques and Szramkiewicz, Romuald: "Recherches sur les conciles des temps mérovingiens", Revue d'Histoire du Droit français et étranger, 49 (1971), p. 5-49.

8 Isidore of Seville, De ecclesiasticis officiis, C. M. Lawson ed., Turnhout, Brepols, 1989 (CCSL 113), II, XXIIII (XXIII), 6 (p. 101, 1. 65-75): Bona quoque temporalia bonis malisque communia a deo creari, eiusque dispensatione singulis quibusque uel tribui uel negari; quorum bonorum in unoquoque fidelium non habitus sed usus aut inprobandus est aut probandus. Certa uero aeternoaque bona solos posse bonos in futuro consequi; quorum pignore ecclesiam nunc informatam credimus detineri, hic habentem primitias spiritus in futuro perfectionem, hic sustentari in spe, postea pasci in re, hic uidere per speculum in enigmate, in futuro autem facie ad faciem cum ad speciem fuerit perducta per fidem. Quod donec perficiatur in nobis ut summi dei bonis fruamur aeternis, fruendum in deo nouerimus et proximis. ${ }^{9}$ Ambrose: De Sacramentis, B. Botte ed., Paris, Cerf, 1961 (Sources chrétiennes, 25 bis) IV, 27: ...et petimus et pecamur uti hanc oblationem suscipias in sublime altare tuum per manus angelorum tuorum, sicut suscipere dignatus es munera pueri tui iusti Abel et sacrificium patriarchae nostri Abrahae et quod tibi obtulit summus sacerdos Melchisedech. See Botte, Bernard: "L'ange du sacrifice et l'épiclèse de la messe romaine au Moyen Âge", Recherches de théologie ancienne et médiévale (1929), p. 285-308.
} 
aristocracy ${ }^{10}$. These inscriptions convey the idea that one finds in heaven the goods distributed to the poor, that one can reach heaven by donating earthly goods ${ }^{11}$.

Roughly speaking, the central question between the fourth and the sixth century is to know how to make good use of earthly goods, what men have been temporarily given by God, enabling them to constitute "treasures in heaven" (Mat. 6, 19-20) and receive "God's real gifts", "the eternal rewards"

A major change takes place in the seventh century as the clergy consolidates his function of intermediation and claims to be indispensable in the conversion of donations of earthly goods into heavenly treasures. This evolution is closely linked to the growing part played by the Church in commemorating the dead. Augustine, who becomes an authority on the question, considers that only the sins of "intermediate" deceased, those who aren't either too bad to be already lost, or too good to be saved, can be redeemed by almsgiving and the prayers of the living ${ }^{13}$. He also believes that the best way to help the dead is to offer the salutary sacrifice and give alms ${ }^{14}$.

According to these principles, which will continuously be used afterwards ${ }^{15}$, even though not mistaken with one another, Eucharistic sacrifice and almsgiving bear similar effects. Concerning practice, in Augustine's times, commemorating the dead during the Eucharistic celebration was an old custom ${ }^{16}$. However, from the end of the sixth century onwards, "private masses" as well as "votive masses" celebrated for the dead appear, steadily growing in number up to the ninth century ${ }^{17}$. These celebrations are supplied with alms, while salvation begins to be a value shared in society, implying that more and more donations are made to churches. Donations with a view to redemption start expanding within a new, very precise documentary context. As was emphasised by

${ }^{10}$ Diehl, Ernest: Inscriptiones latinae christianae veteres, Berlin, Dublin, Zurich, Weidmann, 3 vol., 1925-193., ${ }^{\circ} 46,170,1072,1073,1103,1269,1310,1462,1700,1740,1778,2138 b, 2148,2477 \mathrm{a}$, 2816 bis; RICG, XV, $\mathrm{n}^{\circ} 41,78,172,176,227,249$; RICG, VIII, ${ }^{\circ} 11$.

11 RICG, VIII, 11 - Limoges, Fortunatus, Carmina, IV, 5: v. 17-18 - Plurima pauperibus tribuentes diuite censu, / Misere ad caelos quas sequerentur opes; v. 20-21 - Felices qui sic de nobilitate fugaci, / Mercati in caelis iura senatus habent!

RICG XV, 99 - Vienne, Saint-Pierre (6th c.), l. 19-21: Quin etiam sumpto mercedes addet honore:/Pauper laetus abit, nudus discedit opertus,/Capituus plaudit liber sese esse redemptum.

12 RICG, XV, 121 - Vienne, Saint-Pierre (6th c.): 1. 4 - [quae]rentem munera uera Dei; l. 11 - uicit auaritiam quae uincere cuncta solebat; l. 16 - Saeculis obtinuit praemia... See Magnani, Eliana: "'Un trésor dans le ciel'. De la pastorale de l'aumône aux trésors spirituels (IVe-IXe siècle)", Le Trésor au Moyen Âge, Colloque Bâle-Neuchâtel, novembre 2006, dir. L. Burkart, Ph. Cordez, P.-A. Mariaux, Y. Pottin (Micrologus - forthcoming).

${ }^{13}$ Augustine: Enchiridion, 29, 110, p. 108-109 [De Fide rerum invisibilium. Enchiridion ad Laurentium de fide et spe et caritate..., Turnhout, Brepols, 1969 (CCSL 46)].

${ }_{14}$ Augustine: Sermo, 172, 2 (PL 38, 936): Orationibus vero sanctae Ecclesiae, et sacrificio salutari, et eleemosynis, quae pro eorum spiritibus erogantur, non est dubitandum mortuos adiuvari; ut cum eis misericordius agatur a Domino, quam eorum peccata meruerunt.

${ }^{15}$ Isidore of Seville, De ecclesiasticis officiis, I, XVIII, 11 (p. 22-23, 1. 91-110).

16 Augustine: Sermo, 172, 2 (PL 38, 936): Hoc enim a patribus traditum, universa observat Ecclesia, ut pro eis qui in corporis et sanguinis Christi communione defuncti sunt, cum ad ipsum sacrificium loco suo commemorantur, oretur, ac pro illis quoque id offerri commemoretur.

${ }^{17}$ Amiet, Robert: "Le culte chrétien pour les défunts", À réveiller les morts. La mort au quotidien dans l'Occident médiéval, D. Alexandre-Bidon and C. Treffort eds., Lyon, Presses Univ. de Lyon, Association des amis des bibliothèques de Lyon, 1993, p. 280-281 and "Masses, votive", Dictionary of Middle Ages, t. 8, p. 200-201; Angenendt, Arnold: "Missa specialis: Zugleich ein Beitrag zur Entstehung der PrivatMessen", Frühmitteriaterliche Studien, 17 (1983), p. 153-221. 
Philippe Jobert, first evidence of donatio pro anima are found in the early seventh century $^{18}$, and widely spread afterwards in the Occident.

Rather than the transformation of a juridical act, donations "for the salvation of the soul" represent a juridical formulation of the doctrine. They are the result, the concrete and coherent expression of the doctrine of almsgiving, visible in the very structure of the acts. Analysing acts preambles thus permits to understand the Eucharistic context within which they lie.

In acts as well as in epigraphic inscriptions we find a wide range of actions likely to be compared with donations for the salvation of the soul. As long as they concern the poor, the priests, the monks and the churches, they are seen as charitable works that can be offered to $\operatorname{God}^{19}$. With fragile ephemeral things, one can obtain eternal rewards ${ }^{20}$, transform worldly goods into heavenly wealth, take earthly goods to heaven ${ }^{21}$.

Thanks to this transfer/transformation phenomenon, triggered by charity, donations and good deeds towards the churches and those in the service of God, it is possible to constitute "treasures in heaven". Passages of the Gospel according to Matthew ensure that donators will be able to amass treasures for eternity ${ }^{22}$. However, this "hoarding" depends on those who directly benefit by the donations: Luke $(16,9)$ thus invites to "make to yourselves friends of the mammon of unrighteousness; that when ye fail, they may receive you into everlasting habitations" 23 . It is therefore about forming ties, establishing a "friendship" with those who are in charge of interceding for the donator's salvation.

Gregory "the Great" (d. 604) recounts for instance that someone had discovered how Deusdedit, a devout man, had had a house built in the beyond. The builders

\footnotetext{
${ }^{18}$ Jobert, Philippe: La notion de donation, p. 205-225.

${ }^{19}$ Marculfi Formularum libri duo, A. Uddholm ed. and trans., Uppsala, 1962, p. 18 (qui non minor a Domino retribucio speratur futura pro succiduis contemplante temporibus quam a presens munera pauperibus offerentem), p. 34 (pro eterna retribucionem benefitium), p. 46, 346 (nobis aput aeternum retributorem mercidum suffragia largiantur), etc.; ARTEM $n^{\circ} 4474$ (696 - unde mercis nostra apud Domino retributure perennis temporibus debiat convalere), 3870 (727 - retributorem omnium bonorum dominum Jhesum Christum), 2929 (766 - pro animae suae salutis remedium vel aeterna retributione), 4788 (804 - pro aeterna remuneratione), etc.

${ }^{20}$ Marculfi Formularum libri duo, p. 350: de caducis rebus mercare aeterna.

${ }^{21}$ Marculfi Formularum libri duo, p. 348, 352; Chartae Latinae Antiquiores. Facsimile Edition of the Latin Charters prior to the Ninth Century, t. XIII - France I - H. Atsma and J. Vezin eds., 1981, n 564 $(673)=$ ARTEM $^{\circ}$ 4462: de terrena substantia se transferat in caelestia...

22 Mt 6, 19-21 - nolite thesaurizare vobis thesauros in terra ubi erugo et tinea demolitur ubi fures effodiunt et furantur thesaurizate autem vobis thesauros in caelo ubi neque erugo neque tinea demolitur et ubi fures non effodiunt nec furantur ubi enim est thesaurus tuus ibi est et cor tuum; Mt. 19, 21 - si vis perfectus esse vade vende quae habes et da pauperibus et habebis thesaurum in caelo; Cyprian of Carthage: De opere et eleemosynis, ch. 7 and 20. See Iogna-Prat, Dominique: Ordonner et exclure, p. 211-217; Buc, Philippe: “Conversion of objects", Viator (1997), p. 99-143; Magnani, Eliana: "'Un trésor dans le ciel'...".

${ }^{23}$ Marculfi Formularum libri duo, p. 350: Oportit climenciae princepale, inter citeras peticionis, illut, que pro salute adescribetur et pro divine nominis postolatur, plagabile auditum suscipere et, procul dubium, ad aefectum perducere, quatenus de caduces rebus presente secoli aeterna conquiretur, juxta preceptum Domini dicentis: Facetis vobis amicis de mamona iniquetatis. Ergo de mamona iniquaetatis, juxta ipsius dictum, nos oportit mercare eterna celestia et, dum sacerdotum congrua inpertemus beneficia, retrebutorem Domino ex hoc habyre meriamur in eterna tabernacola [ARTEM ${ }^{\circ} 4483$ (716), 2931 (768), 2935 (769), 2944 (775), 2943 (775) 2953 (778), 4981 (631/32)]. See Cyprian of Carthage: De opere et eleemosynis, ch. 12.
} 
(constructores) only worked on Saturdays: indeed, every Saturday, Deusdedit brought to Saint Peter the surplus of his weekly work so as to give it the poor ${ }^{24}$. Besides the role played by the "friends" who work for their benefactors, this story is an example of the immediate correspondence, in both worlds, between actions, things and the people involved.

In the charters of the seventh to the ninth centuries and after, donators request the intercession (intercedere, intercessio, intercessor) of the Saints and of the Virgin, of the monks "serving Christ" as well as the poor, most of the time through prayers for the remission of $\operatorname{sins}^{25}$. The mediators' place in the relations between men and God is made more complex and reinforced by the multiplicity of possible intercessors. In concrete terms, what is actually consolidated is the clergymen's domination. Through the interplay of correspondences and by reversing the roles, they consider themselves poor, on top of collecting and redistributing the alms to the "real" poor. In doing so, they become necessary media in the communication with the beyond.

The numerous liturgical celebrations dispensed by the monks for the benefactors' salvation, besides prayers, are supposed to be lasting after the donor's death. With the intercession for the souls of the deceased, mass celebration and Eucharistic offering are increasingly compared with alms and donations to churches as a way to obtain the salvation of the soul. In the course of the ninth century, this comparison becomes more obvious. For instance, in acts of Charles the Bold (d. 877), the connection directly made between vineyards that have been given, the wine obtained from them and its use in the Eucharist during the mass celebrated for the King's soul, refers to series of transformations ${ }^{26}$. Worldly goods becoming eternal rewards, the oblation that angels move from the altar here below to the altar on high, the change of bread and wine into the Body and Blood of Christ: all these phenomena are pure mystery. If we refer to Charles the Bold's tutor, Walahfrid Strabo (808/9-849), a parallel can be established between these phenomena and the transformations taught by Christ when instituting a new type of sacrifice, without blood, different from that of the Patriarchs: "He has taught the passage from carnal to spiritual, from the earth to heaven, from temporal to eternal, from imperfection to perfection, from resemblance to substantive, from the image to reality" 27 .

\footnotetext{
${ }^{24}$ Gregory 'The Great': Dialogues, A. de Vogüé ed., P. Antin trans., Paris, Cerf, 1978-1980, 3 vol. (Sources chrétiennes, 251, 260, 265), IV, 38, 1, see also IV, 37, 7-10, 15-16.

25 Marculfi Formularum libri duo, p. 164: Ait enim scribtura: "Absconde aelimosynam in corde pauperis, et ipsa pro te deprecabitur Domino" [Ecc 29, 15]. Abscondamus ergo elimosynam in corde pauperis, ut proveniat nobis deprecatio pauperum ad remissione peccatorum. ARTEM $\mathrm{n}^{\circ} 4511$ (654): ut per intercessionem sanctorum illorum in caelesti regno cum omnebus sanctis mereant particepari et vitam aeternam percipere; 2952 and 2949 (777): ut Dominus per suam misericordiam et intercessiones sanctorum et orationes pauperum mihi in pace et misericordia debeat recipere. See Mclaughlin, Megan: Consorting with Saints: Prayer for the Dead in Early Medieval France, Ithaca (Ill.), Londres, Cornell University Press, 1994.

${ }^{26}$ See Guerreau, Alain: L'avenir d'un passé incertain. Quelle histoire du Moyen Âge au XXIe siècle, Paris, Seuil, 2001, p. 191-205 and "Vinea", Les historiens et le latin médiéval. Colloque tenu à la Sorbonne les 9, 10 et 11 septembre 1999, M. Goullet, M. Parisse eds., Paris, Publications de la Sorbonne, 2001, p. 6773. About Charles the Bold, see Hen, Yitzhak: The royal patronage of liturgy in Frankish Gaul to the death of Charles the Bald, 877, Woodbridge, Boydell \& Brewer, 2001 (Subsidia 3), p. 121-145; Nelson, Janet L.: Charles the Bald, London, New York, Longman, 1992.

27 Walahfrid Strabo: Libellus de exordiis et incrementis quarundam in observationibus ecclesiasticis rerum. A translation and liturgical commentary, A. L. Harting-Correa ed., Leiden-New-York, Köln, E. J.
} 
After the Carolingian shift, the comparison made with Eucharistic types of offering is particularly noticeable in the donations and tax paid to monasteries under the form of wine, wheat or bread, as shown by numerous examples from the tenth century onwards ${ }^{28}$. At the same time, the number of testimonies increases, following the example of oblation, of the charter where a donation or a return of goods is recorded and which is put on the altar, as well as ceremonies taking place down by the altar (penance, reconciliation, resolution of conflicts...).

At that time too, what is expressed in the charters is the need to accompany alms and donations with the conversion of men, to turn sinners into new men. Augustine, by connecting the redeeming efficiency of charity with the real conversion of the heart and the changes in the donor's behaviour, paves the way for a "spiritualist trend" of alms, which implicates those who absolve any sinner for having given alms, without assessing his faults or his way of life ${ }^{29}$. To evoke the necessary transformation of man, certain donation acts refer to a passage in the Book of Ezechiel $(33,11)$, in which God asserts that he does not want the sinner to die but to become a convert and live ${ }^{30}$. This theme reflects the debates that took place in the eleventh century on the quality of donation, either pure or not, depending on the donor's actions, as is recorded in Peter Damian's (d. 1072) correspondence ${ }^{31}$. From the viewpoint of representations, the spreading of these preoccupations in the documents of practice is a turning point, linking the "traditional" transformation of things offered to the transformation of man.

After the first donation acts for the salvation of the soul in the seventh century, the question of transfer and transformation underlies the perception of the processes triggered by alms and donations to churches in the preparation for salvation. The latter is viewed as the obtaining of a recompense from the beyond, which would take the form of an enjoyment proportional to charity practice on earth, these actions aiming at erasing the sins of man. The phenomenon thanks to which worldly goods are turned into everlasting heavenly goods, which makes it possible to constitute "treasures in heaven" and urges "friends" to intercede on behalf of the donor, can be compared to the mystery of the Eucharist. More than in the simple analogy, already present in the third century, between the Eucharistic offering during mass and the goods "sacrificed" for God and his representatives on earth, the mystery lies in the transformation undergone by things to go

Brill, 1996 (Mittellateinische Studien und Texte, 19), p. 102 (et a carnalibus ad spiritualia, a terrenis ad caelestia, a temporalibus ad aeterna, ab imperfectis ad perfecta, ab umbra ad corpus, ab imaginibus ad veritatem docuit transeundum). See Cristiani, Marta: Tempo rituale e tempo storico, comunione cristiana e sacrificio: le controversie eucaristiche nell'alto medioevo, Spoleto, Centro italiano di studi sull'alto Medioevo, 1997, (Collectanea 8).

${ }^{28}$ ARTEM n $^{\circ} 1085$ (911-916), 1820 (926), 3953 (933), 3788 (950), 2508 (951), 2510 (951-2), 1608 (954), 1635 (999), etc.

29 Jobert, Philippe: La notion de donation, p. 172-178.

30 ARTEM n 3994 (1016), 4000 (1021), 4019 (1033), 4028 (1036), 3343 (1086); ARTEM nº 541 (1020): Piissimus ac miserator omnium suorum Dominus, quotidie operariis suis clamat dicens: O cuncti mei coloni, date et dabitur vobis. Ipse iterum dicit: Date helemosina et ecce omnia munda sunt vobis. Certe cunctipotens Dominus quotidie nos expectat, ut convertamur de malum ad bonum de ignorantia ad scientiam de peccatis ad veram penitentiam; ARTEM $n^{\circ} 1664$ (1033): me omni cordis intentione converti.

${ }^{31}$ Peter Damian: Epistolae, K. Reindel ed., Monumenta Germaniae Historica, Die Briefe der deutschen Kaizerzeit, IV, 1, München, 1983, n 14, p. 145-150, see Iogna-Prat, Dominique: Ordonner et exclure, p. 238. 
from one sphere to the other, from here below to the beyond. And only the clergy can execute it. The scope of the stakes around the Eucharist broadens insofar as the clergy intends to impose his pre-eminence on society. The shifts in what is said in the donations preambles are further clues of this process initiated in the Carolingian times and achieved in the seigniorial society. The fact that they managed, in the eleventh century, to connect donations with the conversion of man, to make the altar the place of new rites and to word the different types of transactions (trade, sales, etc...) as donations, evidences that the ecclesiastical doctrine builds around the Eucharistic paradigm the foundations of the representations of social practices.

Abbreviations:

ARTEM - "Atelier de Recherche sur les textes médiévaux “, Université de Nancy, CNRS. See La diplomatique française du haut Moyen Âge. Inventaire des chartes originales antérieures à 1121 conservées en France, par M. Courtois et M.-J. Gasse-Grandjean, sous la dir. de B.-M. Tock, Turnhout, Brepols, 2001, 2 vol.

CCSL - Corpus Christianorum. Series Latina.

PL - Migne, Jacques-Paul, Patrologia Latina, Paris, 1800-1875.

RICG - Recueil des inscriptions chrétiennes de la Gaule antérieures à la Renaissance carolingienne, H.-I. Marrou dir., t. XV. Viennoise Nord (province ecclésiastique de Vienne), F. Descombes ed., Paris, CNRS, 1985; t. VIII. Première Aquitaine, F. Prévot ed., Paris, CNRS, 1997. 
